\title{
Mapping the Development and Processes of Emerging „Green Markets" in the Context of Sustainable Marketing Management
}

\section{Gabriela Pajtinková Bartáková ${ }^{1}$, Katarína Gubíniová ${ }^{1}$, Jarmila} Brtková $^{1}$

${ }^{1}$ Comenius University in Bratislava, Faculty of Management, Odbojárov 10, 82105 Bratislava 25, Slovak Republic, gabriela.bartakova@fm.uniba.sk

\begin{abstract}
.
The global market environment is marked by hyper-competitive market players' uncompromising efforts and activities. In recent years declaring social responsibility principles has become a tool to differentiate their business plans in terms of sustainable development of the future society. One of the significant cultural trends on the threshold of the third millennium is a shift in customers' attitudes towards environmental issues. This trend is documented by numerous studies from around the world. In Slovakia public attitudes mapping towards solving issues around the impact of their consumer behaviour and organizational behaviours has gradually become a more crucial problem. The aim of the paper is an indirect comparative synthesis and mapping of emerging green market representatives' manifestations and attitudes to consumption.
\end{abstract}

Key words: Sustainability. Green markets. Consumer behavior. Sustainable marketing management.

\section{Introduction}

Environmental awareness and environmentally friendly consumer behaviour is influenced not only by economic impulses themselves, but also by a number of incentives of different types and intensity (Volná, Papula 2013). These include for example nature conservation, health protection, ensuring life chances for the future generations and stable economic development etc. Implementation of such goals in real life is often made difficult by unclear current and future daily impact on the environment, often under the influence of expected short-term benefits (Stachová, Stacho 2013).

If an organisation decides to factor the principles of sustainability into its activities, create and improve attributes of sustainable marketing management, then it must firstly identify those customers who will be approachable, favourably disposed to sustainable products and in particular those who will be willing to pay a premium price 
for such products. The term green market is used to distinguish sustainably oriented customers and organizations which are able to attend to them.

Nationwide representative surveys on consumer attitudes towards the environment and studies on environmental awareness clearly indicate attentive perception of ecological problems, as well as accepting environmental protection as an important part of social responsibility. A great majority of respondents is persuaded that the growth limits have been reached and precautions to prevent natural catastrophes (e. g. global warming, air, water and soil pollution) are vitally important (Steffens 2006).

\section{Materials and methods}

The results presented in the paper are based on primary, representative, quantitative and qualitative research, while the main role in the qualitative research is played by motivating factors, which customers find in currently applied in sustainable consumption. The research was conducted from September to November 2014 on a sample of 1,820 respondents. The reliability of the results of the conducted research was at the level of $95 \%$ with precision of $3 \%$, while the sample size represented 1,820 respondents. The sample comprised an adult population of Slovakia based on gender, age, education, nationality, regional representation and size of seat. Evaluation of the questions in the section Findings and discussion have been extracted from the research results.

\section{Problem identification}

The 2007 and 2008 studies of the World Business Council for Sustainable Development state that the green market size is questionable and depends on different understanding of such a market. However, one fact is indisputable - the size of this market shows a growing tendency (World Business Council for Sustainable Development 2008).

In the 2008 report (Hartman Report 2008) the research organization Hartman Group following the trends in the field of customer perception on sustainability states that more than $90 \%$ of customers want to contribute to sustainability in some way. However, only half of them understand the concept of sustainability and they expect lead- 
ership and responsibility from organizations. The report shows a very important fact on the customer side, namely that sustainability issues are important to customers if they affect them personally and directly e. g. for essential consumption products.

Another research organization GfK Roper Consulting publishes an annual Green Gauge Report for organizations that are interested in customer attitudes and behaviour in the green markets. The 2008 report (GfK Roper Consulting 2008) also confirmed a growing trend in the population of the United States, who is interested in sustainability. $72 \%$ of Americans (a year-on-year increase of $10 \%$ ) declared fairly clear knowledge of environmental issues. $28 \%$ of Americans (a year-on-year increase of $20 \%$ ) seek out environmental information and they make so-called green purchases that are savings inspired, but there is also an increasing number of those who buy such products at a premium price. Almost a third of Americans believe that they should be more concerned about the environment. The organization Natural Marketing Institute that leads LOHAS Consumer Trends Database explores the global trends in consumption/sustainable consumption as follows. In all countries surveyed (The European countries represented in the survey: France, Germany, Spain, Belgium, Netherlands, Portugal) price or consumption expenditure is the most frequently reported barrier to purchase decisions for sustainable products and services on the customer side. Approximately two-thirds of customers in all countries deal with the impact on the environment. However, price still remains the critical element of the marketing mix in their purchase decision-making.

Relatively few customers in all countries surveyed are not price sensitive, while customers in the United States are the least willing to pay a premium price.

In the 2009 report the research organization Hartman Group presented another psychographic segmentation scheme for green markets which consists of four segments. These segments (The Hartman Group 2009) differ based on several criteria: concern for social and environmental issues, the frequency and intensity of prosustainability behaviour.

The customers belonging to the outside-sustainability segment have the following characteristics: 
- they believe that benefits of recycling and reusing products are overstated,

- they rarely, if ever, factor ecological and social factors into their purchase behaviours,

- they are not familiar with the term sustainability, they do not understand the concept.

The customers belonging to the inside-sustainability segment have the following characteristics:

- they are twice more than others convinced that it is important to buy and consume environmentally friendly or otherwise sustainable products and services,

- they are four times more than others willing to pay a final price increased by $10 \%$ for sustainable products.

This segment is subdivided into four subsegments as follows.

The core customer segment $(13 \%)$ shows the highest level of involvement in a sustainability lifestyle, including purchasing environmentally friendly products, and adhering to pro-sustainability attitudes. The mid-level segments $(35 \%+31 \%)$ demonstrate a lower level of commitment to sustainability principles and less active purchase behaviour. The periphery customers show only minimal concern for environmental and social sustainability.

GfK Roper Consulting is another research organization that conducts segmentation research in the area of consumer behavior and environmental sustainability.

\section{Results}

Question 1: „To what extent are sustainability principles and environmental characteristics of products important to you in the process of purchase decision-making?“"

As it follows from the research results, $16 \%$ of the surveyed respondents consider environmental sustainability principles to be important in the process of purchase decision-making (of which $5 \%$ very important). These principles are not important to $84 \%$ of the respondents. 
Question 2: „Are you willing to pay a premium price if it is a sustainable product (environmentally friendly product and the like)?“"

The research results point out that Slovak consumers are not willing to pay a premium price for sustainable products, despite their benefits for the society and environment. Up to $87 \%$ of respondents gave a negative opinion in their answers (i. e. rather no or no). On the contrary, only $13 \%$ of respondents said that they are willing to pay a premium price.

Question 3: „To what extent would company activities beneficial to the society and environment affect you ? (e. g. financial contribution to charities or reducing the environmental burden caused by company activities)?"

More than two-thirds of respondents said that company activities which are beneficial to the society and environment do not affect their purchase decisions. $17 \%$ of respondents would prefer products of such a company to competition. For $5 \%$ of respondents it is definitely the reason to buy a product of such a company. $2 \%$ of respondents consider such activities to be a PR stunt and they definitely would not buy a product.

Question 4: „In your opinion are consumers (and general public) well informed about sustainable consumption principles?“"

Up to $88 \%$ of respondents think that they are not well informed about sustainable consumption principles (of which $54 \%$ rather no, $34 \%$ no). Slovak consumers have lack of awareness of how they can reduce their environmental and social impacts for the sake of sustainable consumption. Only $12 \%$ of respondents replied that there is sufficient awareness in this area.

Question 5: „On a scale of 1 to 5 with 1 being the best evaluation and 5 being the worst evaluation, how would you rate availability of sustainable products in the Slovak market?"“

$46 \%$ of respondents rate availability of sustainable products negatively (as 4 and 5). $40 \%$ of respondents consider availability to be average. Only $14 \%$ of respondents rated availability as 1 and 2 . It follows from the above that respondents spend a lot of time and energy searching for truly sustainable products.

Concerning the position of a customer in the concept of sustainable marketing management it is necessary to identify discrepancies be- 
tween attitudes and proactive consumer behaviour. Based on these discrepancies there are five main barriers to sustainable consumer behaviour.

1. Lack of information and awareness: many customers declare that they do not know how to reduce their environmental and social impacts (Vilčeková, Štachoň, Sabo 2013).

2. Negative perception: many customers are convinced that sustainable products are inferior with regard to various attributes such as design, style, and performance.

3. Distrust: many customers have no confidence in statements of marketing managers (e. g. in the form of marketing communication, CSR and sustainability reports). They are often right, because many statements and claims are false and misleading (Hesková, Štarchoň 2009, Kubičková 2009).

4. High prices: many customers (and they are often right) consider sustainable products to be expensive, overpriced and they are not able/willing to pay such a price for them.

5. Low availability: customers spend a lot of time and energy searching for truly sustainable products.

\section{Conclusion}

Building a market position in green consumers' minds should have a distinctive product/brand identity compared to competition (Vilčeková 2014). In order to create the market position of products correctly and strongly enough in consumers' minds (in green markets), an organization must analyze benefits of offered products and services and determine the extent to which they correspond to sustainability values of the target segment.

The way that enables the market position creation through sustainability attributes is development of a product portfolio which will demonstrably meet the sustainability criteria. In other words to create such value attributes complying with the values which the target segment shares. Another strategy is product positioning by emphasizing efficiency and financial savings. 
It is important to emphasize that for implementation of sustainability principles into positioning strategies it is not necessary to position products as green or sustainable. It is extremely vital to highlight the fact that the core of the market position is a good reputation of an organization in the market. This reputation is built not only on using traditional and new marketing communication tools, but nowadays mostly on what "others say about the organization" (Trel'ová 2014). In the age when there are so-called channels on the Internet controlled by customers it is important for organizations to act in a sustainable way, not only passively declare such acting.

Solutions corresponding to the above discrepancies can be derived from sustainable marketing management:

- customer education, (Hitka, Balážová 2015)

- production and extensive distribution of better, sustainable products,

- honest marketing communication, (Olšavský 2013)

- clearer declaration of elements building value.

Consumer education should start with specially adapted teaching tools because of the growing need for information - critical awareness, social and environmental responsibility in terms of sustainable consumption, rights and obligations, well-thought-out decisions, the will to act and all these for realizing and asserting their interests, as well as general interests of consumers/individuals or whole groups (Steffens 2006, Solarová 2014).

\section{Acknowledgements}

This paper was elaborated with the support of the research project VEGA 1/0205/14 - The Prospect of the Existence of Dynamic Service Industries in the Slovak Republic in the Context of the Application of the Principles of Innovation Union.

\section{References}

1. GfK Roper Consulting (2008). Green Gets Real ... Current Economic Environment Subduing Green Enthusiasm but Driving Practical Action. 
2. Hartman Report (2008). Presentation Made during the Northwest Sustainability Discovery Tour in Portland, Oregon.

3. See: HESKOVÁ, M. - ŠTARCHOŇ, P. (2009). Marketingová komunikace a moderní trendy v marketingu. Praha : Oeconomica, $180 \mathrm{p}$.

4. HITKA, M. - BALÁŽOVÁ, Ž. (2015). The Impact of Age, Education and Seniority on Motivation of Employees, Journal Business: Theory and Practice. Vol. 15, No. 1. Litva: Vilnius.

5. KUBIČKOVÁ, V. (2009). Inovačné aktivity podnikov služieb. Bratislava : Ekonóm, 162 p.

6. See also: OLŠAVSKÝ, F. (2013). Generation Approach in Operating of the Target Market - Opportunities and Risks, Theory and Practice in Management. Bratislava: Univerzita Komenského v Bratislave, pp. 122-131.

7. See for example: SOLAROVÁ, P. (2014). Angažovanost spotřebitelů v maloobchodě - získání námětů, Marketing Science \& Inspirations, Vol. 9, No. 1, pp. 16-25.

8. STACHOVÁ, K. - STACHO, Z. (2013). Employee Allocation in Slovak Companies, Business: Theory and Practice, Vol. 14, No. 4, pp. 332-336. Litva: Vilnius, 2015.

9. STEFFENS, H. (2006). Správanie spotrebitelov a spotrebitel'ská politika. Bratislava : Ekonóm, p. 36.

10. The Hartman Group (2009). Sustainability: The Rise of Consumer Responsibility, Executive Summary.

11. See also: TRELOVÁ, S. (2014). Manažér a jeho právne postavenie, $M M K$ 2014. Hradec Králové: Magnanimitas, pp. 5864.

12. VILČEKOVÁ, L. (2014). Etnocetrizmus slovenských spotrebitel'ov, Marketing Science \& Inspirations, Vol. IX, No. 3, pp. 53-59.

13. VILČEKOVÁ, L. - ŠTARCHOŇ, P. - SABO, M. (2013). Segmentation Process in Determining Slovak Consumers' Attitudes Toward Brands, Mathematics and Computers in Contemporary Science. Athens: WSEAS, pp. 206-211.

14. VOLNA, J. - PAPULA, J. (2013) Analysis of the Behavior of Slovak Enterprises in the Context of Low Innovation Per- 
formance. Procedia - Social and Behavioral Sciences, Vol. 99. Amsterdam: Elsevier, pp. 600-608.

15. World Business Council for Sustainable Development (2008). Sustainable Consumption Facts and Trends from a Business Perspective. 